\title{
Mexico: Training health providers on domestic violence
}

\author{
Susan Pick \\ Lydia Miranda
}

Follow this and additional works at: https://knowledgecommons.popcouncil.org/departments_sbsr-rh

Part of the Demography, Population, and Ecology Commons, Domestic and Intimate Partner Violence Commons, International Public Health Commons, and the Women's Health Commons How does access to this work benefit you? Let us know!

\section{Recommended Citation}

Pick, Susan and Lydia Miranda. 1999. "Mexico: Training health providers on domestic violence," FRONTIERS Final Report. Washington, DC: Population Council. 


\title{
Mexico: Training Health Providers on Domestic Violence
}

\author{
Susan Pick and Lydia Miranda \\ Instituto Mexicano de Investigación de Familia y \\ Población, A.C.
}

May 7, 1999

Final report of the project, Expanding Use of a Training Module on Identification and Management of Domestic Violence among Patients of Reproductive Health Care Professionals, conducted in Mexico during January-March 1999. This study was funded by the U.S. AGENCY FOR INTERNATIONAL DEVELOPMENT (USAID) under the terms of Cooperative Agreement number HRN-A-00-98-00012-00, Subproject number 5801.13002.421. The opinions expressed herein are those of the authors and do not necessarily reflect the view of USAID. 


\section{Mexico: Training Health Providers on Domestic Violence}

\section{SUMMARY}

This subproject was designed to disseminate, expand use and promote institutionalization of a program to train health care professionals to address domestic violence. The program was developed and implemented by the Instituto Mexicano de Investigación de Familia y Población, A.C. (IMIFAP), a nongovernmental organization that promotes reproductive health. Under this subproject, IMIFAP staff trained 450 health care professionals based in 14 cities in nine states of Mexico and 21 health providers in Lima, Peru.

IMIFAP designed the 18-hour workshop, entitled "Health Services Respond to Domestic Violence" (Los servicios de salud ante la violencia doméstica) to sensitize health professionals to domestic violence issues and develop strategies for recognizing and managing cases of domestic violence. The course will be replicated throughout the sponsoring institutions, since at least five of the participants in each course will serve as trainers in future courses.

Other activities conducted as part of the project included:

1. Training of trainer's (TOT) sessions in which subsequent courses were planned.

2. Press briefings and interviews in some cities.

3. Distribution of three publications on domestic violence:

- La violencia doméstica. Lo que el personal de salud debe saber (Domestic Violence: What Health Workers Should Know), 1998.

- Venguer, Tere, Gillian Fawcett, Ricardo Vernon, and Susan Pick. Violencia doméstica: una marco conceptual para la capacitación del personal de salud. (Domestic Violence: A Conceptual Framework for Training Health Personnel). Documentos de trabajo, No. 24, Population Council/INOPAL III, México, 1998.

- Fawcett, Gillian, Tere Venguer, Ricardo Vernon, and Susan Pick. Detección y manejo de víctimas de violencia doméstica: desarrollo y evaluación de un programa dirigido al personal de salud. (Detection and Management of Victims of Domestic Violence: Development and Evaluation of a Program for Health Personnel). Documentos de trabajo, No. 26, Population Council/INOPAL III, México, 1998.

4. Distribution of a booklet and poster on emergency contraception. 
5. "Two training programs tailored to Mexican Culture: The Role of Health-Care Providers in Society: a Humanist Approach, and Health-Care Providers Facing Domestic Violence" by Martha Givaudan, Lydia Miranda. Paper presented at Communication in Medicine Conference Northwestern University and University Medical School, July 20-23, 1999.

To evaluate the workshops, IMIFAP administered pre- and post-workshop questionnaires to measure changes in knowledge. In 12 of the 14 workshops for which data are available, strong and significant increases in knowledge about domestic violence and its management in primary health care services were found.

Workshop participants developed new strategies, program plans and lists of referral points. In Xalapa, for example, participants worked six extra hours to write a proposal for modifications to the Veracruz state law, Ley de Asistencia y Prevención de la Violencia Intrafamiliar (Law for Assistance and Prevention of Domestic Violence). In Chiapas, participants developed strategies to work with indigenous women.

Workshop participants recommended several steps to institutionalize the identification and management of domestic violence cases in primary health care facilities:

- Training of staff throughout the health care system to detect, counsel and treat victims of domestic violence;

- Establishment of referral centers specializing in assisting domestic violence victims;

- Development of strategies for improving communication, health services and support for domestic violence victims; and

- Revision of laws governing domestic violence. 


\section{Mexico: Training Health Providers on Domestic Violence}

\section{TABLE OF CONTENTS}

I. INTRODUCTION

II. OBJECTIVES

III. ACTIVITIES

IV. EVALUATION

V. CONCLUSIONS AND RECOMMENDATIONS

APPENDIX

A. Course Descriptions

B. Mean Knowledge of Domestic Violence Issues Before and After Each Workshop 


\section{Mexico: Training Health Providers on Domestic Violence}

\section{INTRODUCTION}

In 1998 the Instituto Mexicano de Investigación de Familia y Población, A.C. (IMIFAP) developed and evaluated a program for health care providers focusing on identification and appropriate treatment of domestic violence victims. This work was supported by the U.S. Agency for International Development under the Population Council /INOPAL III project. IMIFAP held workshops in two institutions, Ticoman Hospital and centers of Desarolla Integral de la Familia (DIF), a government welfare institution. A few weeks later IMIFAP contacted the participants to assess the impact of the workshops. This assessment found that participants had acquired significant knowledge of domestic violence issues, and they planned to improve the situation of patients who suffered domestic violence.

The negative consequences of intimate partner violence on women's physical and mental health have been well documented. ${ }^{1}$ It has also been shown that abuse during pregnancy jeopardizes the health of the mother and her child. ${ }^{2}$ Experts on domestic violence believe that health care providers are strategic actors in the identification of domestic violence victims, since most women visit health services at least once every few years.

\section{OBJECTIVES}

The general objective of this project was to disseminate, expand use and promote the institutionalization of IMIFAP's domestic violence program for health care professionals. IMIFAP's program, Training for Assessment and Intervention in Health Care Settings, was developed for primary health care facilities in Mexico.

The specific objectives were:

1. Carry out training workshops on domestic violence for health care professionals in selected cities throughout Mexico;

\footnotetext{
${ }^{1}$ Heise, L.L., Pitanguy, J. \& Germain, A. (1994). Violence against women. The hidden health burden. Washington D.C.: The World Bank.

${ }^{2}$ Koss, M.P., Koss, P.G., and Woodruff, W.J. (1991). Deleterious effects of criminal victimization on women's health and medical utilization. Archives of Internal Medicine 151(2): 342-347.

${ }^{3}$ Mullen, P.E., Romans-Clarkson, S.E., Walton, V.A., and Herbison, G.P. (1988). Impact of sexual and physical abuse on women's health. Lancet 1(8590): 841-845.
} 
2. Provide follow-up support to workshop participants in order to reinforce issues addressed and information provided in the program;

3. Conduct training of trainers (TOT) sessions in the different cities visited;

4. Conduct media relations activities in each state and nationally; and

5. Distribute printed materials among health care providers to make them aware of the need to detect violence and the alternatives that may be presented to victims of abuse.

\section{ACTIVITIES}

\section{Dissemination of Information about the Program and Promotion of its Adoption}

Between November and December 1999 IMIFAP promoted the workshop on domestic violence for health service providers among several key groups:

- Health institutions - Ministry of Health, Mexican Social Security Institute (IMSS), IMSS-Solidarity, the Social Security and Services Institute for State Workers (ISSSTE);

- State women's programs and feminist NGOs in Chiapas, Coahuila, Tamaulipas, Mexico, Querétaro, Oaxaca, Guanajuato and the Federal District; and

- the IMSS-Solidarity program in Oaxaca, Veracruz, Querétaro and the Federal District.

\section{Training Courses for Health Care Professionals}

Between January and March 1999 IMIFAP conducted 18 training courses for 450 health care professionals in Mexico and 21 service providers in Lima, Peru. The 17 courses held in Mexico covered a large area. Following is a list of the nine states and the 14 cities where courses were convened in Mexico:

- Coahuila (two in Saltillo and one in Piedras Negras)

- México (Cd. Nezahualcoyotl and Cd. Aragón)

- Tamaulipas (Cd. Victoria and Reynosa)

- México City (3)

- Guanajuato (Guanajuato and León)

- Oaxaca (Tlaxiaco and Huajuapan de León)

- Veracuz (Xalapa)

- Querétaro (Querétaro)

- Chiapas (San Cristóbal de las Casas).

The details of each course are presented in Appendix A.

Most workshops lasted for 18 hours and were attended by physicians, nurses, health promoters, and other local health providers. Some participants worked as lawyers, social 
workers and psychologists for government agencies or nongovernmental groups concerned with abuse prevention. Most participants were women. Participants were very enthusiastic. In most cases, they left the workshop with written plans and the clear intention to conduct follow-up activities. In several cities, workshop organizers also ensured that the workshop was covered by local media (see below).

\section{Outreach and Promotional Activities}

Press conferences. In Coahuila and Oaxaca local newspapers and radio stations interviewed the trainers to disseminate information on domestic violence identification and treatment services in local health care facilities. In a few cities, newspaper articles on domestic violence were published (see Appendix B).

Dissemination of materials. All workshop participants received a pamphlet on domestic violence and a poster and pamphlet on emergency contraception:

- La violencia doméstica. Lo que el personal de salud debe saber (Domestic Violence: What Health Workers Should Know);

- Difusión de Información sobre anticoncepción de emergencia en la República Mexicana (Information about Emergency Contraception in Mexico); and

- ¿Te lanzaste sin ningún método anticonceptivo? (Did you "take a dive” with no contraception? -- poster).

Institution coordinators and trainers received two working papers on domestic violence:

- Venguer, Tere, Gillian Fawcett, Ricardo Vernon, and Susan Pick. Violencia doméstica: una marco conceptual para la capacitación del personal de salud (Domestic Violence: A Conceptual Framework for Training Health Personnel). Documentos de trabajo, No. 24, Population Council/INOPAL III, México, 1998.

- Fawcett, Gillian, Tere Venguer, Ricardo Vernon, and Susan Pick. Detección y manejo de víctimas de violencia doméstica: desarrollo y evaluación de un programa dirigido al personal de salud (Detection and Management of Victims of Domestic Violence: Development and Evaluation of a Program for Health Personnel). Documentos de trabajo, No. 26, Population Council/INOPAL III, México, 1998.

\section{EVALUATION}

To evaluate the impact of the workshops, participants filled out questionnaires before and after the workshops. The questionnaires measured changes in knowledge about violence and strategies for managing cases. The self-response questionnaires consisted of a section of five multiple-choice questions and a section of 10 open questions related to knowledge 
about the dynamics of abuse and strategies for handling victims of violence. Results of the before-after comparisons in 14 of the 18 workshops are presented in Appendix B. T-tests with paired samples were conducted.

In 12 of the 14 workshops for which data are available, strong and significant increases in the knowledge regarding the identification and management of domestic violence cases were observed (see Table 1). Items included socioeconomic consequences of violence, intentions of the abuser, types of violence, the violence cycle, physiological symptoms, psychological symptoms, indirect abuse indicators, steps after detection, and an emergency plan. No statistically significant differences were observed in Chiapas and Xalapa. IMIFAP will conduct follow-up visits to see if these results also translated into implementing service delivery changes.

\begin{tabular}{|l|l|}
\hline ISSSTE (State of Mexico) & $\begin{array}{l}\text { Replication of the workshop in one clinic } \\
\text { (Ecatepec) } \\
\text { Introduction of the topic in their daily } \\
\text { practice (Toluca) }\end{array}$ \\
\hline COESPO (León) & $\begin{array}{l}\text { Workshop to revise and discuss violence } \\
\text { issues. They solved doubts and reinforce } \\
\text { knowledge. }\end{array}$ \\
\hline $\begin{array}{l}\text { Colectivo de Reunión entre Mujeres } \\
\text { (Chiapas) }\end{array}$ & $\begin{array}{l}\text { Workshop to revise and discuss violence } \\
\text { issues. They solved doubts and reinforce } \\
\text { knowledge. They need more assistance and } \\
\text { support to continue activities. }\end{array}$ \\
\hline $\begin{array}{l}\text { Servicios de Salud. Subdirección de Salud } \\
\text { Reproductiva del Estado (Tamaulipas) }\end{array}$ & $\begin{array}{l}\text { Workshop to revise and discuss violence } \\
\text { issues. They solved doubts and reinforce } \\
\text { knowledge. }\end{array}$ \\
\hline
\end{tabular}

Table 1. Knowledge Gain Pre- and Post-Workshop on Domestic Violence Topics

\begin{tabular}{|l|l|l|}
\hline Topic & $\begin{array}{l}\text { Number of Sites with Significant } \\
\text { Increase in Knowledge (p > .05) }\end{array}$ & $\begin{array}{l}\text { No Significant } \\
\text { Gain }\end{array}$ \\
\hline Socioeconomic consequences & 7 & 7 \\
\hline Intentions of the abuser & 5 & 9 \\
\hline Types of violence & 10 & 4 \\
\hline Violence cycle & 10 & 4 \\
\hline Physiological symptoms & 9 & 5 \\
\hline Psychological symptoms & 9 & 5 \\
\hline Indirect abuse indicators & 9 & 5 \\
\hline Steps post-detection & 4 & 10 \\
\hline Emergency plan & 9 & 5 \\
\hline
\end{tabular}




\section{CONCLUSIONS AND RECOMMENDATIONS}

Both the evaluation of workshops and the comments made by workshop participants suggest that workshops are a necessary, but not a sufficient condition, for institutionalizing the identification and management of domestic violence cases in primary health care facilities. Sustained follow-up is needed to ensure that staff throughout the health care system receive the necessary training to counsel and treat victims of domestic violence. In addition to training, most areas need to establish institutions and centers specializing in assisting domestic violence victims. Most participants stated that there are few places that

they trust to send their patients for support. In the meantime, they will define strategies for improving communication, health services and support for their patients. 


\section{APPENDIX A}

\section{COURSE DESCRIPTIONS}

\section{COAHUILA}

Of the three courses held in Coahuila state, two of them were held in Saltillo, the state capital, and one in Piedras Negras, a city at the northern frontier of Mexico and the U.S.

\section{Course 1}

An 18-hour training course, Los servicios de salud ante la violencia doméstica, was conducted for health care providers from the Secretaria de Salud y Desarrollo Comunitario, Servicios de Salud de Coahuila at Centro de Rehabilitación y Educación Especial, Saltillo, Coahuila, on February 13, 1999 by Lydia Miranda Eslava (IMIFAP's facilitator). In addition, Ms. Miranda was interviewed by three local newspapers: Vanguardia, Heraldo de Saltillo, and Zócalo.

The course had 25 participants, all female: doctors, nurses, physio-therapists, health promoters, psychologists and lawyers (working for these institutions). The group was well-integrated, motivated and interested in domestic violence. Most of the participants work in first assistance service centers - Centro de Salud Integral de la Mujer, Defensoría Jurídica, Hospital de la Mujer. Others work for institutions with indirect contact with women, but they need to know how to assist them - Casa de los Niños y las Niñas de Coahuila; Casa Cuna DIF, Casa del Joven CAIF-DIF, and Secretaria de Salud training coordinators.

The group found IMIFAP's approach very useful. They were interested in the concepts as well as the personal, emotional and professional aspects of domestic violence. Participants had some knowledge about the topic, since they already assist women and children who are victims of domestic violence, but they reported that they had learned more about both the concepts and practical strategies for detection. They were enthusia stic about making their own support networks and links for collective participation in the prevention and assistance. They were interested in follow-up contacts to evaluate their own activities. All participants were interested in continuing their training for the implementation of this program in their institution.

\section{Course 2}

An 18-hour training course, Los servicios de salud ante la violencia doméstica, was given to health care providers for Secretaria de Salud y Desarrollo Comunitario, Servicios de Salud de Coahuila, at the Hospital Estatal de la Mujer, Secretaría de Salud Saltillo, Coahuila, by Lydia Miranda Eslava (IMIFAP's facilitator), on February 4-5, 1999. The 26 participants - two men and 24 women -consisted of doctors, nurses, physiotherapists, health promoters, psychologists and lawyers working in those centers.

The group was formed during February 1-3. Participants asked the facilitator to give the course, since they had not been able to join the first course. This enthusiasm showed they were very motivated and interested, so the course was given in the morning and afternoon on holidays. Most of the participants work in first assistance service centers: Centro de Salud Integral de la Mujer, 
Defensoría Jurídica, Hospital Estatal de la Mujer, and Escuela de Estudios Técnicos de Enfermería. Others work for institutions with indirect contact with women, but they need to know how to assist them: Casa de los Niños y las Niñas de Coahuila; Casa Cuna DIF, Casa del Joven CAIF-DIF, and Secretaria de Salud training coordinators.

Because they work directly with victims of domestic violence, participants had some knowledge about this topic. They said that they had learned more about the conceptual framework as well as practical strategies for detection.

\section{Course 3}

An 18-hour training course: Los servicios de salud ante la violencia doméstica, was conducted for health care providers employed by Secretaria de Salud y Desarrollo Comunitario, Servicios de Salud de Coahuila, Jurisdicción \# 1, in Piedras Negras, Coahuila (frontier city with the United States), by Lydia Miranda Eslava, on February 8-10, 1999. In addition, Ms. Miranda was interviewed by two local newspapers and for the radio Radiorama, Crystal - FM, Piedras Negras (cassette, tapescript).

The 29 participants -10 male and 19 female - consisted of doctors, teachers of medicine, students in medicine, nurses, students in nursing, health promoters, psychologists, and social workers.

Participants stated that they had partial knowledge of domestic violence but had learned more about it. Initially the group was reluctant to participate in the emotional and sensitizing activities, but as the course progressed they openly shared their personal and professional experiences. They expressed interest in searching for special agencies in their community to support victims of domestic violence. They knew of only two such specialized places: SI Mujer (Salud Integral para la Mujer) and Defensoría Jurídica Integral, Gobierno del Estado de Coahuila.

\section{ESTADO DE MÉXICO}

Two courses were held in the state of México - in the cities of Nezahualcoyotl and Aragón.

\section{Course 1}

An 18-hour training course, Los servicios de salud ante la violencia doméstica, was held for health care providers from the Instituto de Salud del Estado de México, Jurisdicción \# 9, in Cd.

Nezahualcoyotl, Estado de México by Rosenda Martínez, on February 15-17, 1999. Although 40 participants were expected, only 17 participants attended the sessions. Participants worked as nurses, health promoters, psychologists and social workers; there were no doctors.

Few of the participants had prior knowledge of the course content and objectives. Some participants said that they had been required to attend the course. Nevertheless, they became committed to the topic as they progressed through the course. They remarked that it had been completely different from their expectations. The course sensitized them to their personal and professional experiences. Due to their increased awareness of the problem of domestic violence, they expressed interest in multiplying this program in their own health centers. 


\section{Course 2}

An 18-hour training course, Los servicios de salud ante la violencia doméstica, was conducted for health care providers employed by Coordinación de Educación e Investigación Médica del Hospital Regional 196, Instituto Mexicano del Seguro Social (IMSS), Ciudad Aragón, Estado de México by Lydia Miranda, on February 16, 18, 23, and 251999.

The 30 participants were very enthusiastic. They included physicians, nurses, health promoters, psychologists, social workers, and doctors' assistants from four IMSS institutions: the host hospital (\#196), a clinic (\#92), Hospital de Traumatología Magdalena de las Salinas, Siglo XXI and Troncoso Hospital. Some of the participants had attended a previous conference on domestic violence and patient assistance, so they understand the course objectives. Participants were very interested in taking an active role in detecting domestic violence and providing the most appropriate assistance to victims. They were willing to continue follow-up activities to reinforce their newly acquired knowledge as well as have supervision in their work.

\section{TAMAULIPAS}

Two courses were held in the cities of Victoria and Reynosa.

\section{Course 1}

An 18-hour training course, Los servicios de salud ante la violencia doméstica, was given to health care providers working in Servicios de Salud, Subdirección de Salud Reproductiva del Estado deTamaulipas, by Mario Zárate, on March 10-12,1999, in Ciudad Victoria.

The 29 participants -three men and 26 women - worked as doctors, psychologists, nurses and social workers. They came from cities in the central and southern region of the state: Tampico, Madero, Cd. Mante, Juamave and Cd. Victoria.

The group was well integrated, since they had met before in counseling training courses. Participants said that they would try to establish some support networks in addition to the registration strategy they planned to start.

\section{Course 2}

An 18-hour training course, Los servicios de salud ante la violencia doméstica, was conducted for health care providers from the Servicios de Salud, Subdirección de Salud Reproductiva del Estado deTamaulipas; by Mario Zárate on March 15-17 1999, in Reynosa.

The 32 participants - five males and 27 females - worked as doctors, psychologists, nurses and social workers; there was also one lawyer, who assists women victims of domestic violence. The participants came from border cities in the northern region of the state: Nuevo Laredo, Reynosa, Valle Hermoso, Río Bravo, Matamoros and San Fernando.

This group was open and willing to work. They were well integrated and freely discussed their clinic and legal cases as well as their personal experiences. The high level of participation made a profound impression on the participants. They vowed to work hard after the course to establish new 
ways of sustained victim assistance. They also planned to present a proposal to the municipal government for the establishment of a shelter for victims of domestic violence.

\section{CIUDAD DE MÉXICO}

Three courses were conducted in Mexico City - two for the Instituto Mexicano del Seguro Social (IMSS) and one for Instituto de Seguridad y Servicios Sociales de los Trabajadores del Estado (ISSSTE).

\section{Courses 1 and 2}

An 18-hour training course, Los servicios de salud ante la violencia doméstica, was conducted for health care providers employed by Dirección de Enseñanza de la Unidad Médica Familiar \#45, del Instituto Mexicano del Seguro Social (IMSS), Iztacalco, México, D.F.; by Judith Vera on the mornings of March 22-26 1999.

Due to scheduling difficulties, the group was split into two. Because all employees had to work their regular eight-hour shift in addition to attending the course, each participant attended 3.5-hour sessions in either the morning or afternoon for five days. These abbreviated sessions made it difficult to complete the necessary course activities.

Thirty participants attended the entire course - eight men and 22 women. They worked as doctors, nurses, dentists, medical assistants, social workers and psychologists. Five people - the clinic subdirector and four department coordinators - attended parts of the course. They were very enthusiastic about the course but missed some sessions due to their workload.

Both morning and afternoon groups participated enthusiastically in all activities and commented on their experience constantly. Two women shared their personal experiences as victims of domestic violence - one from her spouse and the other from her father. Participants appreciated the opportunity to be sensitized on domestic violence and be reminded of their important role in giving support and primary assistance to women who suffer from domestic violence. They emphasized the importance of training health care professionals.

\section{Course 3}

An 18-hour training course, Los servicios de salud ante la violencia doméstica, was held for health care providers from the Subdirección de Enseñanza e Investigación of the Instituto de Seguridad y Servicios Sociales de los Trabajadores del Estado (ISSSTE), México, D.F.; by Francisco Fernández, on March 29-31, 1999.

The 37 participants - six men and 31 women - worked as doctors, nurses, social workers and psychologists. All participants felt they needed more information about domestic violence, since they face these cases in their patients. The group was sensitive and open to new ideas. The varied occupations of the participants enriched the course. 


\section{GUANAJUATO}

\section{Course 1}

An 18-hour training course, Los servicios de salud ante la violencia doméstica, was conducted for health care providers from the Programa Estatal de la Mujer (COESPO), Proyecto No violencia hacia la mujer, Guanajuato, Gto., by Hilda Ramírez on March 22-23, 1999.

The 28 participants - all female - worked as social workers and psychologists for the state health ministry. They came from several cities: Guanajuato, Irapuato, Celaya, Silao, Salamanca, Valle de Santiago, and Dolores Hidalgo. One participant was from COESPO. The participant from Silao is working with a new NGO to set up a project to assist women victims of violence.

The group was very dynamic and participated actively in the workshop. All of them were strongly committed to helping victims of domestic violence. They expressed interest in replicating the course.

\section{Course 2}

An 18-hour training course, Los servicios de salud ante la violencia doméstica, was conducted for health care providers from the Consejo Municipal de Participación de la Mujer y Dirección de Salud Municipal, León, Guanajuato; by Hilda Ramírez on March 24-26, 1999.

The 33 participants - all female - worked as doctors, social workers, psychologists, and lawyers. They were highly committed to working with victims of violence and reported that they see such cases very frequently. Participants noted the lack of institutional structures to support these cases. The existing centers have managers with "machismo" attitudes; they also lack trained personnel. Participants developed an address book of institutions for patient referrals and shared ideas for interinstitutional strategies that could be coordinated by the municipal council and could lead to changes in legislation.

\section{XALAPA, VERACUZ}

An 18-hour training course, Los servicios de salud ante la violencia doméstica, was conducted for health care providers working for the Centro de Atención a Víctimas de la Procuraduría General de Justicia del Estado de Veracruz, en Xalapa; by Rosenda Martinez on March 21-22, 1999.

The organizers expected 30 participants, but 51 people turned up. To accommodate the large number of people, they were split into two groups. All of the participants were women; they worked as doctors, nurses, social workers and lawyers.

Most of the participants were familiar with domestic violence because of their work. However, most of them had negative attitudes toward women who suffer violence. As the course progressed, the participants, especially lawyers, said that after becoming more aware of what violence means and how it affects women's lives, they were more enthusiastic about doing their best to help victims of violence. 
Participants formulated ideas for a proposal to reform certain aspects of the Ley de Asistencia y Prevención de la Violencia Intrafamiliar. Another proposal was to organize a public event during Women's Health Day on May 28, 1999. This event would include talks and visual and printed materials about domestic violence, both for prevention and assistance. Participants also elaborated ideas for new pamphlets about domestic violence. All of the participants and facilitator gathered for five more hours to draft these proposals.

\section{QUERÉTARO}

An 18-hour training course, Los servicios de salud ante la violencia doméstica, was conducted for health care providers from Coordinación de Salud Reproductiva y Materno Infantil, Delegación, Querétaro, Instituto Mexicano del Seguro Social (IMSS), Querétaro; by Francisco Fernández on March 22-24, 1999.

The 28 participants - three men and 25 women - consisted of social workers, nurses, and psychologists, plus one physician and two residents. Although they were initially unsure of the course content, they became increasingly involved and committed as it progressed. They were very inquisitive and willing to apply their new knowledge. They shared their professional and personal experiences. A psychologist who tried to interpret the course from a psychoanalytic and therapeutic point of view found it difficult to apply this perspective.

\section{OAXACA}

\section{Course 1}

An 18-hour training course, Los servicios de salud ante la violencia doméstica, was held for health care providers employed by the Instituto Mexicano del Seguro Social IMSS Solidaridad del Estado de Oaxaca; in Huajuapan de León, by Hilda Ramírez on March 29-30, 1999.

The 16 participants consisted of two women (a physician and a health promoter) and 14 male physicians and public health promoters. The health promoters were reticent to participate; they seemed to be intimidated by the physicians. Women in the group were constant and firm in their participation. Those who were participatory had valuable insights and proposals. The physicians were very interested in creating new strategies to face violence issues. It was hard to fulfill some objectives of the course due to gender issues. Most of the men had difficulty in approaching or being close to other men when the activity required such contact. The group discussed this behavior and related it to the obstacles health staff face in giving appropriate assistance to victims.

The participants greatly appreciated the IMIFAP course. Because women in their area are controlled by their partners, they suggested that a comprehensive program to address domestic violence needs to work with the men. The program would integrate domestic violence prevention and assistance to victims. They formulated proposals to inform women and their partners about domestic violence through talks, posters, and other channels. They also recognized the importance of case registration. Currently there are no specialized centers or trained people in official institutions. 


\section{Course 2}

An 18-hour training course, Los servicios de salud ante la violencia doméstica, was held for health care providers at the Instituto Mexicano del Seguro Social IMSS Solidaridad del Estado de Oaxaca by Mario Zárate on March 29-30, 1999.

The 24 participants -- 11 women and 13 men - consisted of physicians, public health promoters, nurses and social workers. Participants were enthusiastic about the course because they thought that it had direct relevance to their work, and in some cases to their personal lives. They stated that they had not realized that domestic violence was so complicated and devastating. Initially, health professionals reported that they had not detected cases of violence. As the course progressed, they acknowledged that they had had such cases and had not been able to detect them. Participants recommended that their immediate supervisors should take the IMIFAP training course. Their main problem in addressing domestic violence is that there are no specialized institutions in their region to refer patients. The nearest facilities are in the capital city.

Mario Zárate was interviewed by the radio station La Poderosa, AM (transmitting for the Mixteca) for a program broadcast on April 1, 1999. The interview focused on domestic violence and IMIFAP's work in this area. A copy of the program will be sent to IMIFAP.

\section{CHIAPAS}

An 18-hour training course, Los servicios de salud ante la violencia doméstica, health care providers affiliated with the Colectivo de Reunión entre Mujeres, San Cristobal de las Casas, Chiapas by Lydia Miranda on March 29-31, 1999.

The 15 participants - 14 women and one man - consisted of three doctors, six psychologists, three indigenous midwives, two social workers, and four indigenous health promoters. They came from San Cristobal de las Casas and Comiitán. Ten additional participants were expected but they did not have the funds to attend. Only 13 participants answered the complete pre/post questionnaires.

The group was very sensitized and knowledgeable about domestic violence issues. They found IMIFAP's approach very useful for their work, since they work directly with victims of violence. The sessions focused on identifying new strategies for supporting indigenous women victims of domestic violence.

\section{LIMA, PERU}

An 18-hour training course, Los servicios de salud ante la violencia doméstica, was held at the Population Council office in Lima, Perú by Francisco Fernández and Judith Vera on February 2426, 1999.

The 21 participants - 20 women and one man - were psychologists, social workers and a sociologist who work for NGO's on projects dealing with gender and domestic violence. Participants were very experienced in domestic violence. They put a lot of effort into the workshop, but they were also very demanding. Some of them had different points of view from IMIFAP's approach. They shared their experience in Peru, which enriched this course. 
The course presented some difficulties for the facilitators because it was planned at short notice and they had little information on the local situation regarding domestic violence. 


\section{APPENDIX B}

\section{Mean Knowledge of Domestic Violence Issues Before and After Each Workshop}

\begin{tabular}{|c|c|c|c|c|}
\hline WORKSHOP & \multicolumn{4}{|c|}{ ARAGON } \\
\hline ITEMS & $\begin{array}{c}\text { MEAN } \\
\text { BEFORE }\end{array}$ & MEAN AFTER & $\mathrm{T}$ & $\mathrm{P}$ \\
\hline Socioeconomic consequences & .55 & .83 & -3.24 & .004 \\
\hline Intentions of the abuser & .40 & .73 & -3.90 & .001 \\
\hline Types of violence & .44 & .96 & -7.76 & .000 \\
\hline Violence cycle & .00 & .80 & -14.23 & .000 \\
\hline Physiological symptoms & .20 & .69 & -5.44 & .000 \\
\hline Psychological symptoms & .54 & .74 & -2.32 & .032 \\
\hline Indirect abuse indicators & .00 & .18 & -4.27 & .000 \\
\hline Steps post-detection & .33 & .65 & -3.57 & .002 \\
\hline Emergency plan & .20 & .84 & -12.41 & .000 \\
\hline WORKSHOP & \multicolumn{4}{|c|}{ CD. VICTORIA } \\
\hline ITEMS & $\begin{array}{c}\text { MEAN } \\
\text { BEFORE }\end{array}$ & MEAN AFTER & $\mathrm{T}$ & $\mathrm{P}$ \\
\hline Socioeconomic consequences & .46 & .8 & -4.44 & .000 \\
\hline Intentions of the abuser & .76 & .87 & -1.53 & .136 \\
\hline Types of violence & .60 & .97 & -10.22 & .000 \\
\hline Violence cycle & .00 & .89 & -18.88 & .000 \\
\hline Physiological symptoms & .35 & .71 & -3.66 & .001 \\
\hline Psychological symptoms & .57 & .77 & -2.73 & .011 \\
\hline Indirect abuse indicators & .00 & .49 & -4.20 & .000 \\
\hline Steps post-detection & .37 & .72 & -6.53 & .000 \\
\hline Emergency plan & .00 & .86 & -12.30 & .000 \\
\hline WORKSHOP & \multicolumn{4}{|c|}{ GUANAJUATO } \\
\hline ITEMS & $\begin{array}{c}\text { MEAN } \\
\text { BEFORE }\end{array}$ & MEAN AFTER & $\mathrm{T}$ & $P$ \\
\hline Socioeconomic consequences & .48 & .72 & -2.75 & .011 \\
\hline Intentions of the abuser & .60 & .88 & -3.64 & .001 \\
\hline Types of violence & .46 & 1.00 & -5.49 & .000 \\
\hline Violence cycle & .11 & .92 & -10.39 & .000 \\
\hline Physiological symptoms & .11 & .58 & -5.78 & .000 \\
\hline Psychological symptoms & .46 & .80 & -4.92 & .000 \\
\hline Indirect abuse indicators & .00 & .20 & -4.61 & .000 \\
\hline Steps post-detection & .51 & .82 & -3.90 & .001 \\
\hline Emergency plan & .00 & .94 & -23.56 & .000 \\
\hline
\end{tabular}




\begin{tabular}{|c|c|c|c|c|}
\hline WORKSHOP & \multicolumn{4}{|c|}{ IMSS D.F. } \\
\hline ITEMS & $\begin{array}{c}\text { MEAN } \\
\text { BEFORE }\end{array}$ & MEAN AFTER & $T$ & $P$ \\
\hline Socioeconomic consequences & .46 & .66 & -2.30 & .030 \\
\hline Intentions of the abuser & .54 & .86 & -3.21 & .004 \\
\hline Types of violence & .53 & .95 & -6.91 & .000 \\
\hline Violence cycle & .00 & .81 & -12.79 & .000 \\
\hline Physiological symptoms & .26 & .54 & -4.04 & .000 \\
\hline Psychological symptoms & .36 & .64 & -3.41 & .002 \\
\hline Indirect abuse indicators & .00 & .21 & -3.70 & .001 \\
\hline Steps post-detection & .36 & .58 & -2.88 & .009 \\
\hline Emergency plan & .17 & .87 & -7.97 & .000 \\
\hline WORKSHOP & \multicolumn{4}{|c|}{ CHIAPAS } \\
\hline ITEMS & $\begin{array}{c}\text { MEAN } \\
\text { BEFORE }\end{array}$ & MEAN AFTER & $\mathrm{T}$ & $\mathrm{P}$ \\
\hline Socioeconomic consequences & .50 & .58 & -1.00 & .363 \\
\hline Intentions of the abuser & .50 & .83 & -2.00 & .102 \\
\hline Types of violence & .38 & .88 & -5.47 & .003 \\
\hline Violence cycle & .17 & .78 & -3.84 & .012 \\
\hline Physiological symptoms & .53 & .53 & -.277 & .793 \\
\hline Psychological symptoms & .63 & .67 & -1.58 & .175 \\
\hline Indirect abuse indicators & .00 & .21 & -2.66 & .045 \\
\hline Steps post-detection & .33 & .71 & -2.00 & .102 \\
\hline Emergency plan & .38 & .71 & -1.93 & .101 \\
\hline WORKSHOP & \multicolumn{4}{|c|}{ OAXACA } \\
\hline ITEMS & $\begin{array}{c}\text { MEAN } \\
\text { BEFORE }\end{array}$ & MEAN AFTER & $\mathrm{T}$ & $P$ \\
\hline Socioeconomic consequences & .58 & .63 & -4.32 & .674 \\
\hline Intentions of the abuser & .42 & .88 & -4.75 & .001 \\
\hline Types of violence & .33 & .98 & -6.49 & .000 \\
\hline Violence cycle & .00 & .78 & -7.00 & .000 \\
\hline Physiological symptoms & .15 & .57 & -3.42 & .006 \\
\hline Psychological symptoms & .23 & .58 & -3.55 & .004 \\
\hline Indirect abuse indicators & .00 & .27 & -2.49 & .030 \\
\hline Steps post-detection & .40 & .60 & -1.70 & .117 \\
\hline Emergency plan & .00 & .58 & -4.69 & .001 \\
\hline
\end{tabular}




\begin{tabular}{|c|c|c|c|c|}
\hline WORKSHOP & \multicolumn{4}{|c|}{ LEON } \\
\hline ITEMS & $\begin{array}{c}\text { MEAN } \\
\text { BEFORE }\end{array}$ & MEAN AFTER & $T$ & $P$ \\
\hline Socioeconomic consequences & .48 & .80 & -3.78 & .001 \\
\hline Intentions of the abuser & .59 & .93 & -4.10 & .001 \\
\hline Types of violence & .65 & 1.00 & -7.27 & .000 \\
\hline Violence cycle & .02 & .92 & -12.16 & .000 \\
\hline Physiological symptoms & .52 & .02 & -4.77 & .000 \\
\hline Psychological symptoms & .61 & .73 & -1.68 & .106 \\
\hline Indirect abuse indicators & .02 & .02 & -1.28 & .213 \\
\hline Steps post-detection & .55 & .58 & -3.35 & .741 \\
\hline Emergency plan & .17 & .91 & -11.41 & .000 \\
\hline WORKSHOP & \multicolumn{4}{|c|}{ MEXICO D.F. } \\
\hline ITEMS & $\begin{array}{c}\text { MEAN } \\
\text { BEFORE }\end{array}$ & MEAN AFTER & $\mathrm{T}$ & $\mathrm{P}$ \\
\hline Socioeconomic consequences & .55 & .71 & -2.07 & .047 \\
\hline Intentions of the abuser & .64 & .88 & -4.83 & .000 \\
\hline Types of violence & .46 & 1.00 & -13.35 & .000 \\
\hline Violence cycle & .00 & .95 & -25.58 & .000 \\
\hline Physiological symptoms & .45 & .71 & -4.11 & .000 \\
\hline Psychological symptoms & .59 & .79 & -2.64 & .013 \\
\hline Indirect abuse indicators & .00 & .28 & -4.96 & .000 \\
\hline Steps post-detection & .56 & .65 & -1.15 & 259 \\
\hline Emergency plan & .13 & .90 & -12.78 & .000 \\
\hline WORKSHOP & \multicolumn{4}{|c|}{ PIEDRAS NEGRAS } \\
\hline ITEMS & $\begin{array}{c}\text { MEAN } \\
\text { BEFORE }\end{array}$ & MEAN AFTER & $\mathrm{T}$ & $P$ \\
\hline Socioeconomic consequences & .55 & .75 & -1.79 & .088 \\
\hline Intentions of the abuser & .63 & .78 & -1.55 & .137 \\
\hline Types of violence & .80 & .98 & -2.66 & .015 \\
\hline Violence cycle & .24 & .68 & -6.83 & .000 \\
\hline Physiological symptoms & .26 & .51 & -5.22 & .000 \\
\hline Psychological symptoms & .46 & .66 & -2.43 & .025 \\
\hline Indirect abuse indicators & .00 & .10 & -1.79 & .088 \\
\hline Steps post-detection & .54 & .63 & -.979 & .340 \\
\hline Emergency plan & .20 & .84 & -9.82 & .000 \\
\hline
\end{tabular}




\begin{tabular}{|l|c|c|c|c|}
\hline \multicolumn{1}{|c|}{ WORKSHOP } & \multicolumn{4}{c|}{ QUERETARO } \\
\hline \multicolumn{1}{|c|}{ ITEMS } & $\begin{array}{c}\text { MEAN } \\
\text { BEFORE }\end{array}$ & MEAN AFTER & $\mathrm{T}$ & $\mathrm{P}$ \\
\hline Socioeconomic consequences & .63 & .71 & -.825 & .420 \\
\hline Intentions of the abuser & .61 & .92 & -4.60 & .000 \\
\hline Types of violence & .51 & 1.00 & -7.86 & .000 \\
\hline Violence cycle & .00 & .89 & -14.26 & .000 \\
\hline Physiological symptoms & .34 & .69 & -3.39 & .003 \\
\hline Psychological symptoms & .43 & .70 & -3.04 & .007 \\
\hline Indirect abuse indicators & .02 & .16 & -2.79 & .012 \\
\hline Steps post-detection & .47 & .53 & -.622 & .542 \\
\hline Emergency plan & .20 & .86 & -8.42 & .000 \\
\hline
\end{tabular}

\begin{tabular}{|l|c|c|c|c|}
\hline \multicolumn{1}{|c|}{ WORKSHOP } & \multicolumn{4}{c|}{ REYNOSA } \\
\hline \multicolumn{1}{|c|}{ ITEMS } & $\begin{array}{c}\text { MEAN } \\
\text { BEFORE }\end{array}$ & MEAN AFTER & $\mathrm{T}$ & $\mathrm{P}$ \\
\hline Socioeconomic consequences & .54 & .56 & -.204 & .840 \\
\hline Intentions of the abuser & .54 & .86 & -3.36 & .003 \\
\hline Types of violence & .37 & .99 & -13.50 & .000 \\
\hline Violence cycle & .00 & .99 & -74.00 & .000 \\
\hline Physiological symptoms & .30 & .83 & -7.85 & .000 \\
\hline Psychological symptoms & .45 & .82 & -4.59 & .000 \\
\hline Indirect abuse indicators & .00 & .24 & -4.90 & .000 \\
\hline Steps post-detection & .42 & .85 & -4.68 & .000 \\
\hline Emergency plan & .30 & .96 & -25.45 & .000 \\
\hline \multicolumn{1}{|c|}{ WORKSHOP } & \multicolumn{2}{|c|}{ SALTILLO } & \\
\hline \multicolumn{1}{|c|}{ ITEMS } & MEAN & MEAN AFTER & T & P \\
\hline Socioeconomic consequences & .35 & .65 & -2.89 & .007 \\
\hline Intentions of the & .63 & .81 & -2.47 & .019 \\
\hline Types of violence & .63 & .99 & -5.73 & .000 \\
\hline Violence cycle & .34 & .95 & -16.21 & .000 \\
\hline Physiological symptoms & .24 & .55 & -4.31 & .000 \\
\hline Psychological symptoms & .53 & .77 & -3.45 & .002 \\
\hline Indirect abuse indicators & .00 & .15 & -2.71 & .011 \\
\hline Steps post-detection & .44 & .46 & -.260 & .797 \\
\hline Emergency plan & .30 & .85 & -11.653 & .000 \\
\hline
\end{tabular}




\begin{tabular}{|l|c|c|c|c|}
\hline \multicolumn{1}{|c|}{ WORKSHOP } & \multicolumn{4}{c|}{ OAXACA } \\
\hline \multicolumn{1}{|c|}{ ITEMS } & $\begin{array}{c}\text { MEAN } \\
\text { BEFORE }\end{array}$ & MEAN AFTER & $\mathrm{T}$ & $\mathrm{P}$ \\
\hline Socioeconomic consequences & .68 & .45 & 1.75 & .095 \\
\hline Intentions of the abuser & .50 & .65 & -1.55 & .137 \\
\hline Types of violence & .30 & .98 & -11.71 & .000 \\
\hline Violence cycle & .00 & .93 & -17.99 & .000 \\
\hline Physiological symptoms & .19 & .51 & -3.81 & .001 \\
\hline Psychological symptoms & .29 & .53 & -3.22 & .004 \\
\hline Indirect abuse indicators & .00 & .19 & -2.88 & .010 \\
\hline Steps post-detection & .40 & .78 & -5.09 & .000 \\
\hline Emergency plan & .20 & .95 & -26.91 & .000 \\
\hline \multicolumn{1}{|c|}{ WORKSHOP } & \multicolumn{4}{|c|}{ XALAPA } \\
\hline \multicolumn{1}{|c|}{ ITEMS } & MEAN & MEAN AFTER & $\mathrm{T}$ & $\mathrm{P}$ \\
\hline Socioeconomic consequences & .57 & .64 & -.618 & .547 \\
\hline Intentions of the abuser & .61 & .89 & -2.82 & .014 \\
\hline Types of violence & .59 & 1.00 & -8.25 & .000 \\
\hline Violence cycle & .34 & .79 & -8.00 & .000 \\
\hline Physiological symptoms & .49 & .77 & -2.92 & .012 \\
\hline Psychological symptoms & .68 & .70 & -.27 & .793 \\
\hline Indirect abuse indicators & .00 & .16 & -1.23 & .239 \\
\hline Steps post-detection & .59 & .63 & -3.60 & .720 \\
\hline Emergency plan & .11 & .79 & -7.05 & .000 \\
\hline
\end{tabular}

